\title{
LA FÁBRICA COMO ESPACIO DE LUCHA Y DE MEMORIA, EL CASO DE BILBAO Y LA MARGEN IZQUIERDA (1975-1995)
}

\section{THE FACTORY AS A SPACE OF FIGHT AND MEMORY, THE CASE OF BILBAO AND THE LEFT BANK (1975-1995)}

\author{
David Beorlegui \\ Universidad del País Vasco, UPV/EHU
}

ORCID: https://orcid.org: 0000-0002-8982-5513

Recibido el 14-8-2017 y aceptado el 20-2-2018

Resumen: Varias investigaciones han insistido en la importancia de la fábrica en el contexto de las sociedades modernas, y han señalado a la desindustrialización como un elemento distintivo del último cuarto del siglo Xx. El artículo recoge esos puntos de vista para abordar la memoria del movimiento obrero en la ciudad de Bilbao y en la Margen Izquierda de los ríos Ibaizabal y Nervión. Valiéndose de una metodología de historia oral, el texto analiza los efectos de la desindustrialización en las personas que participaron de la oleada de huelgas y manifestaciones que se desarrolló en la zona durante los últimos años de la dictadura, destacando el rol que desempeñan las emociones en la conformación del recuerdo del mundo obrero. La euforia reivindicativa de mediados de los años setenta y la angustia creciente se alimentan del paisaje de ruina industrial y conectan el pasado con el presente, dando significado de modo retrospectivo a la memoria del mundo obrero en el período estudiado.

Palabras clave: Movimiento obrero, emociones, memoria, desindustrialización.

Abstract: Several investigations have insisted on the importance of the factory in the context of modern societies and have pointed to deindustrialization as a distinctive element of the last quarter of the twentieth century. The article gathers these points of view to address the memory of the labor movement in the city of Bilbao and in the Left Margin of the Ibaizabal and Nervión rivers. 
Using an oral history methodology, the text analyzes the effects of deindustrialization on the people who participated in the wave of strikes and demonstrations that took place in the area during the last years of the dictatorship, highlighting the role played by the emotions in the conformation of the memory of the labor movement. The euphoria of the demands of the mid-seventies and the growing anxiety before the disappearance of the working world feed on the landscape of industrial ruin and connect the past with the present, giving a retrospective meaning to the memory of the working world in the period studied.

Keywords: Working class movement, emotions, memory, deindustrialization. 


\section{Introducción}

«No me lo podía creer. El cinturón de la margen izquierda no existe... La clase obrera ha desaparecido» ${ }^{1}$. Las palabras de Oliva Esteban dan cuenta de la sensación de devastación experimentada a mediados de los años noventa por parte de toda una generación de trabajadores y trabajadoras que habían configurado su subjetividad al hilo de las grandes movilizaciones acontecidas durante los últimos años del franquismo, dando la sensación de que con la desaparición de las grandes industrias de la zona había perdido en el tiempo a una parte de sí misma. Ante los ojos de esta antigua trabajadora de la Naval de Sestao se levantaban cientos de ruinas que se distribuían a lo largo de los catorce kilómetros que separan a la ciudad de Bilbao del mar, en una superficie de casi tres millones de metros cuadrados. Hoy todavía pueden apreciarse junto a las orillas de la ría los restos de las grandes grúas de desembarco de carbón y de los muelles de descarga, mientras uno/a imagina las chimeneas de los Altos Hornos que ocuparon un papel preponderante en un paisaje durante más de un siglo, expresando, en opinión del experto en transformación urbana Isusko Vivas, la «identidad moderna» de Bizkaia ${ }^{2}$. En su relato de vida, Oliva Esteban destaca el rol emblemático desempeñado por las fábricas humeantes en la margen izquierda, «la parte que está ahora como degradada», definiendo su ser a partir de una ausencia melancólica que aúna en la memoria la materia, el tiempo y el espacio: «Yo las llamo las catedrales desaparecidas - asegura - tengo todas mis vivencias, toda mi historia, toda mi vida... la tengo aquí...»³.

Como han planteado Cowie y Heathcott, la desindustrialización es uno de los procesos más característicos e importantes de la experiencia de la modernidad, exigiendo la adopción de perspectivas complejas para su estudio, al implicar toda una serie de transformaciones económicas, espaciales, culturales y políticas que desafían los límites tradicionalmente impuestos por la disciplina histórica ${ }^{4}$. El siguiente artículo está dedicado a

1 Entrevista a Oliva Esteban. Fecha de realización: 12-02-2009. Oliva Esteban nació en 1952 (fecha aproximada) en Burgos, pasando a vivir a Sestao a la edad de cuatro años. Fue trabajadora de la Naval de Sestao y formó parte de las Comisiones Obreras desde 1974, pasando posteriormente al Colectivo Autónomo de Trabajadores (CAT) y combinando su actividad con su militancia en el MC/EMK.

2 Vivas, 2007, p. 37.

${ }^{3}$ Entrevista a Oliva Esteban, realizada por Mentxu Irusta Laforga (extracto).

${ }^{4}$ Cowie y Heatcott, 2003, p. 2. 
analizar los efectos que tuvo la desindustrialización en las personas que participaron del movimiento obrero vizcaíno durante los últimos años de la dictadura franquista y los inicios de la transición política, a partir de una revisión crítica del concepto de la ruina y una indagación en las relaciones afectivas que entabla el pasado fabril en el caso de quienes desarrollaron su experiencia militante en los grandes centros de producción distribuidos a lo largo de la Margen Izquierda. El texto sugiere que el devenir de la identidad obrera estuvo muy determinado por los cambios experimentados por el espacio industrial, alimentándose tanto de la euforia experimentada durante la oleada de huelgas que sacudió los centros de trabajo a mediados de los años setenta como de la melancolía que resultó del cierre y desmantelamiento de esas empresas a lo largo de la década siguiente. Ambos procesos confluyen en la memoria y arrojan de modo retrospectivo una experiencia caracterizada por una suma ambivalente de emociones que se materializa en una nueva configuración subjetiva, especialmente proclive a la afectividad nostálgica asociada a las ruinas industriales.

El articulo defiende que el caso del desmantelamiento del tejido industrial bilbaíno constituye una muestra extrema de la radicalización de las fuerzas motrices de la sociedad moderna en su estadio tardío, de una sensación de aceleración temporal que apunta a disolver la experiencia humana del tiempo en un eterno presente ${ }^{5}$. Podemos identificar esas fuerzas o tendencias con el anhelo de futuro que caracterizó al movimiento obrero durante los años setenta y con la desaparición de ese horizonte de liberación a lo largo de la década siguiente, revelando la cara más cruenta de la modernidad, aquella que como planteó Marshall Berman «amenaza con destruir todo lo que tenemos, todo lo que somos [...] en una vorágine de perpetua desintegración y renovación. De lucha y contradicción, de ambigüedad y angustia. Ser modernos es formar parte de un universo en el que, como dijo Marx, <todo lo sólido se desvanece en el aire>» ${ }^{6}$. El primero de los apartados está dedicado a explorar el significado emocional adquirido por la fábrica durante los últimos años de la dictadura y los inicios de la transición política, al hilo de una oleada de huelgas y protestas que quedó incorporada por sus protagonistas como una parte irrenunciable de la experiencia del período y aparece en la memoria como un an-

\footnotetext{
5 Deluze y Guattari, 2004, p. 321. Rolnik y Guattari, 2006, p. 255.

${ }^{6}$ Berman, 1989, p. 1.
} 
tecedente inmediato de la crisis del mundo obrero. El segundo apartado está dedicado a analizar el menoscabo de esa atmósfera de combatividad y sus sustitución por una afectividad melancólica que se vio incrementada durante los años ochenta y terminó por apoderarse de los espacios fabriles, al hilo del cierre, abandono y desmantelamiento de las grandes industrias de la margen izquierda.

La mirada melancólica que se cierne sobre el paisaje post-industrial y parece sepultar los valores emancipadores asociados al mundo obrero se asemeja a la visión benjaminiana sobre el ángel de la historia, que lo describe siendo arrastrado irremisiblemente hacia el futuro por un progreso que destruye todo a su paso y deja tras de sí un cúmulo de ruinas y escombro, informando del carácter contingente de la propia existencia y del mundo que le circunda ${ }^{7}$. Andreas Huyssen ha considerado, profundizando en esa interpretación, que la 'ruinificación' conforma el corazón mismo de la modernidad, dado que ésta arrastra consigo hacia el futuro todo lo existente, convirtiendo el presente en un cúmulo de ruinas que se amontonan unas sobre otras ${ }^{8}$. Poniendo en valor la centralidad del espacio de la fábrica en el marco de las sociedades modernas, la especialista Alice Mah ha empleado el término 'ruination' para referirse a todo un proceso vivido de cierre, demolición re-utilización de las antiguas fábricas, enmarcándolo en un contexto amplio de paisajes y legados generacionales que tienen su principal fuente emisora en la memoria ${ }^{9}$. Navaro-Yashin, por su parte, ha optado por ese término para aludir los restos materiales de la destrucción y la violencia, pero también las subjetividades y los afectos residuales que emergen como secuelas de una transformación traumática del espacio $^{10}$. Este tipo de consideraciones resultan de gran utilidad para analizar las subjetividades resultantes del proceso desindustrializador vizcaíno y el deterioro experimentado por las identidades militantes de corte más obrerista a lo largo de los años ochenta.

Durante casi cien años Bilbao había constituido en el centro neurálgico de la industrialización en Bizkaia y en el País Vasco ${ }^{11}$. La importancia de la fábrica en el Bilbao de la modernidad tardía exige atender al modo en que la vida humana se despliega históricamente en una con-

\footnotetext{
7 Benjamin, 2008, pp. 44-45.

${ }^{8}$ Huyssen, 2010, pp. 18-21.

9 Mah, 2012, p.11. Strangleman, 2013, pp. 23-37. Cowle y Heatcott, 2003, pp. 2-3.

10 Navaro-Yashin, 2009.

11 González Portilla, 2001, p. 100.
} 
tingencia tanto espacial como temporal, de tal manera que ese espacio producido socialmente aparece tanto como el resultado como el medio en el que acontece la vida social. Como advierte Eduard Soja, ese carácter construido del espacio tiene implicaciones inmediatas en la memoria, dado que las historias de vida se van desarrollando en una línea cronológica jalonada por una serie de milieux o posiciones específicas, emplazamientos que afectan a los pensamientos, acciones y emociones que se despliegan en ellos ${ }^{12}$. El artículo analiza las disposiciones afectivas que provoca el recuerdo del mundo fabril en el caso de los y las militantes obreras que desarrollaron su actividad en los grandes centros de producción de la margen izquierda. El texto defiende la existencia de dos emociones distintas; la euforia y la melancolía, que confluyen en el recuerdo y dotando de significado al auge y el ocaso del mundo industrial y de la lucha obrera.

Los conceptos de territorio y desterritorialización resultan de gran utilidad para una investigación centrada en explorar las relaciones que el tiempo y el espacio entablan a la memoria, permitiendo aludir al proceso de cambios que experimentaron las subjetividades en el transcurso del proceso de desindustrialización vizcaíno. Para Deleuze y Guattari el territorio está situado en una encrucijada afectiva en la que confluyen una gran cantidad de elementos, tanto de tipo material como simbólico, terminando por constituir un espacio vivido que es fuente de seguridad existencial. Ese espacio en el que se ordenan las distintas posiciones que ocupan los sujetos en el tiempo puede desmoronarse o abandonarse, dando lugar a un instante de suspensión del sentido en la vida que se resuelve en la creación de otro territorio. Ese movimiento funciona en una doble dirección y opera de modo simultáneo, esto es, va incorporando nuevos materiales en pos de una construcción subjetiva y se desprende al mismo tiempo de otros que pasan a formar parte del pasado $^{13}$. Se entiende que la memoria y las emociones desempeñarían un papel muy importante en todo ese proceso y en el caso de las subjetividades que sometemos a análisis, las de los y las militantes del movimiento obrero, resultan unas herramientas imprescindibles, permitiendo analizar la relación afectiva que se establece con la fábrica en el recuerdo, en tanto que territorio asociado a la militancia, al futuro y al progreso, así como para entender el gesto de desterrito-

\footnotetext{
12 Soja, 1989, p. 14.

13 Vattimo, 1986, p. 146
} 
rialización que introduce la desindustrialización en tanto que fractura en la experiencia del tiempo y del espacio.

La historia oral aparece como la metodología más adecuada para una investigación centrada en la experiencia militante del espacio fabril y el significado que esta adquiere en la memoria. Por una parte, la metodología de «historias de vida» en la que nos hemos basado está dirigida a obtener una base de información sobre la cultura material del mundo obrero, necesaria para esclarecer las hipótesis planteadas durante el transcurso de la investigación ${ }^{14}$. Por otro lado, el enfoque trata de comprender a los sujetos desde la fenomenología existencial y observar las formas concretas que se abren, experiencias dotadas de historicidad, que remiten a un «ser en el mundo» que emerge en unas determinadas coordenadas de tiempo y espacio ${ }^{15}$. Desde una perspectiva fenomenológica que sitúa a la memoria y la subjetividad en el centro del análisis, la historia oral permite comprender «cómo la gente conecta su experiencia y su contexto social, cómo el pasado deviene parte del presente, y cómo la gente lo emplea para interpretar sus vidas y el mundo que les rodea» ${ }^{16}$. Las fuentes utilizadas para la redacción de este artículo proceden de la realización de entrevistas con antiguos trabajadores y trabajadoras de las grandes industrias vizcaínas que desarrollaron una labor sindical durante los años del tardofranquismo y la transición. La mayoría de estas personas estuvieron vinculados a formaciones y corrientes de la izquierda radical, si bien se ha optado por incluir también testimonios de informantes relacionados con otras organizaciones. El cómputo general de entrevistas utilizadas para la redacción de este artículo asciende a veintiséis, distribuidas en las colecciones «Luchas Obreras en Bizkaia», y «Activismo sociopolítico en el País Vasco durante los años setenta y ochenta», depositadas en el Archivo de la Memoria/ Ahozko Historiaren Artxiboa ${ }^{17}$.

14 Berthaux, citado en Mejía, 2000.

15 Llona, 2010, p. 177.

16 Frisch, citado en Perks y Thomson, 2003, p. 3.

17 Todas las entrevistas han sido realizadas por Mentxu Irusta y proceden de la colección «Luchas obreras en Bizkaia», con la excepción de las realizadas a Mario García y Enrique Ramos, de la colección. «Activismo sociopolítico durante los años setenta y ochenta», entrevistas realizadas por David Beorlegui. 


\section{La fábrica durante el tardofranquismo: entre el cielo gris y la aurora roja}

La fábrica fue para el caso de Bilbao y su comarca un escenario que dio significado a la experiencia de la modernidad. El testimonio de José Ramón Castaños, veterano militante comunista y antiguo trabajador de Altos Hornos, resulta muy revelador de la incorporación del paisaje industrial como una parte del propio ser y de la identidad obrera en las poblaciones de la margen izquierda, cuando asegura, con respecto a las fábricas, que: «Habíamos nacido con ellas, nos hemos criado con ellas... y nos parecían eternas» ${ }^{18}$. Rosa García, trabajadora de General Eléctrica y militante obrera durante mas de dos décadas, da cuenta también de la importancia de la fábrica en su localidad y en toda su juventud, afirmando que: «yo nací en Sestao, en la plaza Urbinaga. Lo que es, lo fue... el meollo de Sestao de la industrialización. Allí estaba, rodeada de todas las fábricas.... ${ }^{19}$. Desde la antropología del espacio, Paul Connerton ha propuesto el término locus para aludir a la parte del espacio que es incorporada como propia por la memoria, un lugar que «está ahí» y cuya existencia se ignora por parte de quienes viven y se mueven en él, en el sentido de darse por sentada, se asume como un aspecto regular de lo que las cosas son $^{20}$. Como planteara Zygmunt Bauman, la fábrica representó mejor que ningún otro espacio a lo largo del siglo veinte el vínculo entre capital y mano de obra que había dado forma a la modernidad: se trataba de «su domicilio común, simultáneamente campo de batalla de una guerra de trincheras y hogar natural de sueños y esperanzas» ${ }^{21}$.

Las grandes fábricas ubicadas junto a la capital vizcaína se vieron beneficiadas a partir de los años cincuenta de su relación privilegiada con el Instituto Nacional de Industria y recibieron fuertes inversiones por parte de los organismos competentes, en una operación que comportó importantes beneficios para los propietarios y entrañó una importante transfor-

18 Entrevista José Ramón Castaños. Fecha de realización: 01/11/2008. José Ramón Castaños nació en 1950 en la zona minera. Fue trabajador de Altos Hornos desde finales de los años sesenta y formó parte de Comisiones Obreras, en una actividad que combinó con su militancia política en ETA, ETA VI y LKI.

19 Entrevista Rosa García. Fecha de realización: 03/12/2009. Rosa García nació en 1942 en Sestao. Fue trabajadora de General Eléctrica y militante de Comisiones Obreras durante los años setenta.

${ }^{20}$ Conerton, 2009, p. 34.

21 Baumann, 2002, p. 154. 
mación social y económica del territorio ${ }^{22}$. Muchas de las poblaciones construidas junto a esos centros de producción estaban definidos por un marcado componente de clase que constituye un elemento común en muchas las historias de vida estudiadas. Así, a la hora de referirse a las características de su vecindario en Santurtzi. Amando Obregón plantea satisfecho que procedía de: «un barrio muy... muy obrero. Muy obrero, pero de los obreros de los últimos, de los de abajo» ${ }^{23}$. De modo muy similar, José Luis Longarte, veterano sindicalista y trabajador de Euskalduna, recuerda que «yo nací en el barrio de Rekaldeberri (en Bilbao) del cual estoy orgullosísimo, en el seno de una familia obrera...». Mari Carmen Saiz también apunta en su relato con respecto a la localidad de Sestao que «vivíamos en este barrio.. que ves que es un barrio grande. Nuestros padres eran todo trabajadores de Altos Hornos. Era... una realidad [...] que es la de las grandes empresas de la Margen Izquierda...» ${ }^{24}$. Otro entrevistado, Luis Miguel Pariza, de Sestao, se describe afirmando que «mi mundo está en la historia de la Margen Izquierda y del mundo del trabajo (...) Mi padre, trabajador de la Naval. Mi abuelo, de Altos Hornos. Mi otro abuelo, de la Naval...» 25 .

Euskalduna, la Naval, Altos Hornos, Astilleros del Cadagua, La Basconia, Altos Hornos, Babcock Wilcox, General Eléctrica, Tarabusi, Echevarría, Aurrerá, Artiach, Unquinesa, Sefanitro, Mefesa, Cromoduro, Firestone... toda una serie de fábricas se distribuían a lo largo de las localidades que rodeaban a la ciudad y se distribuían fundamentalmente por la Margen Izquierda de la ría . Geles González, trabajadora de General Eléctrica, señala mediante una anécdota significativa muchas de esas empresas eran consideradas un sinónimo de posibilidad de ascenso social y buenos salarios durante los años sesenta: «era cuando se contaba aquel chascarrillo de "dame una chuleta, que mi marido trabajaba en la

${ }^{22}$ Pérez, 2001, p. 365. Serrabim 2012, p. 114.

23 Entrevista Amando Obregón. Fecha de realización: 01/03/2009. Amando Obregón nació en Burgos en 1953 y fue trabajador de Altos Hornos y miembro del MC/EMK.

${ }^{24}$ Entrevista Luis Miguel Pariza. Fecha de realización: 26/06/2009. Luis Miguel Pariza nació en Sestao en 1951. Entró a trabajar en Babcock Wilcox con 18 años, militando durante décadas en el sindicato UGT.

25 Entrevista Mari Carmen Saiz. Fecha de realización: 08/01/2009. Mari Carmen Saiz nació en 1953 en Portugalete y fue trabajadora de General Eléctrica, miembro de Comisiones Obreras y del MC/EMK. Posteriormente abandonó Comisiones y pasó al sindicato ESK. 
Gene" (risas) ${ }^{26}$. Como ha señalado Rafael Ruzafa, esos centros de producción podían considerarse «auténticos emblemas sociales a partir de los cuales se había formado y desarrollado la comarca» ${ }^{27}$. El bullicio y el ajetreo que caracterizaban a los espacios de sociabilidad obrera también resultaban elementos muy característicos de los barrios del Bilbao fabril y de su memoria. Mario García, por ejemplo, evoca su juventud durante los años sesenta aludiendo al espectáculo que ofrecían las masas de trabajadores al acudir a la ciudad tras concluir el turno en la fábrica: «todos salían de trabajar cuando tenían jornada partida a los mediodías y a las tardes el poteo. Eso lo recuerdo, lo tengo aquí grabao, porque era increíble, era una cosa de vamos, de cientos y cientos, venga para arriba y para abajo...» ${ }^{28}$.

Los grupos de fábrica que proliferaron a partir de la segunda mitad de los años setenta estuvieron en los orígenes de un nuevo movimiento obrero que desempeño un importante papel opositor y que tomó cuerpo en gran medida en torno a las conocidas como Comisiones Obreras ${ }^{29}$. Como recuerda José Luis Longarte, las grandes fábricas de la margen izquierda formaron parte de ese proceso desempeñaron un papel crucial en la conformación de un nuevo territorio para la militancia, formado por una serie reivindicaciones laborales que se mezclaban en otras de carácter más social y político y eran impulsadas desde células clandestinas: «se llamaban comisiones de trabajadores, comisiones obreras - rememora Longarte- Nos interrelacionábamos entre las diferentes fábricas. Sobre todo las más mayores, ¿no? Altos Hornos, La General, la Babcock, Euskalduna, Echebarria... y entonces esa coordinación, pues claro, estaba perseguida por la policía ${ }^{30}$. En una línea similar, Txutxi Korres, trabajador

26 Entrevista Angeles González. Fecha de realización: 03-01-2009. Ángeles González nació en Ortuella en 1943. Fue trabajadora de General Eléctrica, miembro de Comisiones Obreras y del MC/EMK.

27 Ruzafa, 2017,p. 5.

28 Entrevista Mario García (seudónimo. Fecha de realización: 03/12/2012. Mario García nació en Bilbao en 1962. Fue miembro de la Liga Comunista y participó del intento de refundación de la CNT, pasando posteriormente a UGT.

${ }_{29}$ Zufiaur, en Soto y Aroca, 2012, p. 19. Gálvez, 2008, p. 201. Ruiz, 1993. Ibarra, 2016, p. 66. Rubio, De la Granja, De Pablo, 2011, pp. 219-220, Pérez, 2013.

${ }^{30}$ Entrevista José Luis Longarte. Fecha de realización: 10/02/2009. José Luis Longarte nació en 1933 en Bilbao. Fue trabajador de Euskalduna y miembro del sindicato USO desde 1960 a 1979, desarrollando un papel muy destacado. Posteriormente formó parte de la asamblea de Euskalduna. 
de General Eléctrica y promotor de huelgas durante los años setenta, enfatiza el tamaño de aquellas empresas y el volumen de sus plantillas, así como la creciente preocupación de las esferas del poder dictatorial ante la inminente gestación de una oposición organizada en la clandestinidad desde el interior de los centros de trabajo: «La General en aquella época tendría alrededor de cuatro mil obreros - señala Korres - la BabcockWilcox igual tenía alguno más... Altos Hornos tendría el doble. Luego estaba la Naval. Era una cantidad y unos movimientos de gente muy grandes, importantísimos. Las autoridades franquistas tenían cierto respeto también.... ${ }^{31}$.

Desde finales del siglo diecinueve e inicios del veinte la Margen Izquierda se había configurado como uno de los núcleos históricos del socialismo, permitiendo contar con la presencia de algunos veteranos sindicalistas en la reconstrucción del movimiento obrero. Estos dirigente aparecían investidos de una aureola mítica para la nueva generación de militantes que hizo su entrada en el movimiento a partir de finales de los años sesenta. Enrique del Hoyo, que se integró en Comisiones a inicios de los años setenta y desarrollaría un importante papel en el conflicto de Euskalduna, considera con respecto a esas personas que: «los líderes sindicales estaban ahí... para nosotros eran unos ídolos» ${ }^{32}$. Cabe citar también la descripción que Joaquín Alcalde efectúa de los dirigentes obreros que conoció al comenzar su trabajo: eran «una gente más formal que la leche», «gente sana», «dispuestos a hacerlo todo por nada» ${ }^{33}$. En una línea muy similar a la planteada por otros entrevistados, José Ramón Castaños también ofrece una descripción que enfatiza el «impacto» que le causaron «los dirigentes sindicales de Comisiones Obreras de entonces, que cada dos por tres iban a la cárcel (...) Para mí, aquellos eran referentes, eran mitos, era una aspiración para nosotros» ${ }^{34}$.

31 Entrevista a Txutxi Korres. Fecha de realización : 10/03/2009. Txutxi Korres nació en Bilbao en 1949. Fue trabajador de General Eléctrica y miembro de Comisiones Obreras, combinando esa labor con su militancia en ETA y posteriormente EIA y Euskadiko Ezkerra.

${ }^{32}$ Entrevista a Enrique del Hoyo. Fecha de realización: 06/03/2009. Enrique del Hoyo nació en Burgos en 1953. Fue trabajador de Euskalduna, miembro de Comisiones Obreras y de la la Liga Comunista Revolucionaria (LCR/LKI).

${ }^{33}$ Entrevista a Joaquín Alcalde. Fecha de realización: 14/02/2009. Joaquín Alcalde nació en Abanto-Ziérbena en 1954. Fue trabajador de Nervacero y miembro de Comisiones Obreras durante los años setenta.

${ }^{34}$ Entrevista a José Ramón Castaños. 
La misión redentora que se atribuía al movimiento y la clandestinidad a la que se veía obligada la lucha fabril, invistieron a la identidad obrera de un halo de misterio y fascinación que resultó indudablemente atractivo a quienes optaron por incorporarse al movimiento durante los últimos años de la dictadura: «gentes que andaban en cosas prohibidas - asegura Gaudencio Alonso, que trabajó en los astilleros de la ría durante décadas - así sonaban ${ }^{35}$. Al relatar su historia, este antiguo trabajador de General Eléctrica, no duda en destacar la «ilusión y el firme convencimiento» experimentados en esos momentos de conformación de las primeras células de militantes, así como la expectativa y la emoción que entrañaba la posibilidad de «poner en la fábrica una línea de trabajo de esta naturaleza» ${ }^{36}$. En un magma de movilizaciones y solidaridad creciente, el entrevistado entiende que el movimiento obrero se percibía a sí mismo a finales de la década en «una fase de ascenso... una época de recuperación de ilusiones». En palabras de Juanjo San Sebastián, la creencia en los atributos excepcionales de la identidad obrera motivó que se viera tentado, como otros de su generación, por una «vocación de ir a la fábrica a salvar al mundo». Quizá sea la primacía de esa relación mítica entre la fábrica y la revolución que existía entonces y que prevalece en el recuerdo de lo sucedido lo que explique que este militante comunista supiera desde que tenía muy tierna edad lo que quería ser de mayor: «quería ser obrero y quería militar en política» ${ }^{37}$.

La envergadura adquirida por el componente obrero en el marco de la lucha antifranquista motivó que muchos militantes se proletarizaran con rapidez durante la primera década de los setenta. Como recuerda Luis Alejos, esa fue una época en que «hasta los hijos de familias bien situadas iban a la fábrica», movidos por el convencimiento de que «había

35 Entrevista a Gaudencio Alonso. Fecha de realización 17/02/2009. Gaudencio Alonso nació en 1952 en Sandoval de la Reina (Brugos). Trabajó en Astilleros Zamacona, Astilleros Españoles y otras empresas similares en la margen izquierda. Fue miembro de la ejecutiva provincial de Comisiones Obreras y militante de ETA VI/LCR/LKI

${ }^{36}$ Entrevista a Jon Fano. Fecha de realización: 20/03/2009. Jon Fano nació en Erandio en 1945. Fue trabajador de General Eléctrica y formó parte de Comisiones Obreras, pasando posteriormente a LAB. Combinó su trabajo sindical con su militancia política en ETA/ETA VI/LCR/LKI.

37 Entrevista a Juanjo San Sebastián. Fecha de realización: 03/03/2009. Juanjo San Sebastián nació en Bilbao en 1055. formó parte de las comisiones de trabajadores y del movimiento asambleario y fue miembro de LCR/LKI hasta 1983. 
que hacer la revolución, y la tenían que hacer los obreros» ${ }^{38}$. En su caso, el hecho de «aborrecer» la fábrica no impidió que finalmente encontrara trabajo en los grandes astilleros vizcaínos y que afirmara que su labor política favorecía una experiencia distinta del lugar de trabajo, la Naval, porque «en la medida que te comprometes ya tienes otra visión» ${ }^{39}$. Iñaki Markiegi recuerda también que fue a la Babcock-Wilcox porque «había una dinámica de acercarnos al mundo laboral. Yo no procedía de ese ambiente». La importancia adquirida por el elemento obrerista para la izquierda en esa época es uno de los aspectos que Mariví Marañón destaca en su relato de vida, cuando narra las causas que la llevaron a tomar la decisión de que «yo no estudiaba más, que pa qué... ahora que están las fábricas. A hacer la revolución. Objetivo: hacer la revolución. ¿Dónde se hace la revolución? Pues en las fábricas ${ }^{40}$. Podemos afirmar, empleando una terminología bajtiniana, que la fábrica constituye un cronotopo, una concepción particular del tiempo y del espacio que se genera por la materialidad del mundo, que impregna los lugares de emociones y valores y condensa el significado de una época en la memoria ${ }^{41}$.

Para comienzos de la década de los setenta la fábrica se había convertido en un sinónimo de actividad militante y un territorio atravesado por una ilusión creciente, que se alimentaba tanto de la debilidad que manifestaba la dictadura franquista como del crecimiento de los movimientos opositores articulados desde los centros del trabajo, en un signo indiscutible de que las cosas estaban cambiando ${ }^{42}$. Joaquín Alcalde asegura que durante la primera mitad de la década ese ambiente se hizo sentir en las granes empresas vizcaínas: «se veía un algo que queríamos cambiar - relata Alcalde - Las organizaciones obreras empezaban a salir a la luz y a dar la cara. A decir: "yo soy de izquierdas"» ${ }^{43}$. Salus San José también

38 Entrevista a Luis Alejos. Fecha de realización: 31/03/2009. Luis Alejos nació en Palencia en 1943. Fue trabajador de la Naval y miembro independiente de Comisiones Obreras y de la COS. Formó parte de pasando posteriormente a MC/EMK.

39 Entrevista a Luis Alejos.

40 Entrevista a Mariví Marañón. Fecha de realización: 01/10/2009. Mariví Marañón nació en Medina de Pomar (Burgos) en 1943. Fue trabajadora de Iberduero y desempeñó un activo papel en la conformación de grupos de fábrica durante los años setenta y ochenta, centrando su actividad en las mujeres. Fue miembro de Comisiones Obreras y de EMK. Posteriormente fue una impulsora del movimiento feminista.

41 Bajtin, 1981.

42 Domènech, 2012, p. 165.

43 Entrevista a Joaquín Alcalde. 
plantea de modo similar el ambiente de conflictividad que dominaba en el interior de General Eléctrica desde que entró en la empresa: «Con diecisiete años, empiezas a ver - relata este antiguo militante- empiezan a llegarte cosas [...] te llegan escritos, te llegan hojas, empiezas a leer... Yo creo que es esa historia, no hay un momento, es un proceso...» ${ }^{44}$. De modo muy similar, Ana Picaza sostiene con respecto a los últimos años de la dictadura que en Babcock Wilcox: «funcionaba bastante aquello de los panfletos, las octavillas, mucha gente tenía en los cajones de la mesa o en las taquillas del lavabo, octavillas y propaganda con diversas cosas, ¿no? (...) Entonces eso era la vida laboral continua...» ${ }^{45}$.

Para la altura de 1975, el ambiente de conflictividad de la Margen Izquierda era tan alto que algunos autores han llegado a afirmar que parecía anunciar «el final inminente de una época» ${ }^{46}$. José Vicente Ojinaga percibía que en la Westinghouse: «las cosas habían pegado un cambiazo enorme en dos años... De no ver nada, a estar todo el puto día en la calle con huelgas..., se ve un algo...» ${ }^{47}$. Enrique Ramos, impresionado por el poderío exhibido por el movimiento desde las áreas industriales, se afana en describir la sensación transmitida por las columnas compuestas por numerosos obreros que acudían a manifestarse a Bilbao: «... desde Arrigorriaga, la Papelera y por ahí. ¡Todos con buzos!. ¡La hostia!, ¡Una movida muy grande!...» ${ }^{48}$. Txutxi Korres también alude a aquella oleada de huelgas para insistir en la incondicionalidad del apoyo mostrado por parte de las localidades obreras, evocando: «...el sentimiento y la solidaridad de toda esa gente sencilla [...]. Todas las mañanas ahí, danzando de un sitio para otro, comiendo un bocata ahí, haciendo frío... eso era increíble,

${ }^{44}$ Entrevista Salus San José. Fecha de realización: 11/01/2009. Salus San José nació en Sestao en 1950. Fue trabajador de General Eléctrica y miembro de Comisiones Obreras, pasando posteriormente a ESK. También fue militante del MC/EMK.

45 Entrevista a Ana Picaza. Fecha de realización: 12/02/2009. Ana Picaza nació en Sestao en 1953. Fue trabajadora de Babcock Wilcox. Participó del movimiento asambleario y posteriormente pasó a conformar grupos de mujeres en las fábricas.

46 La expresión tomada de Pérez, 2001, p. 365. Ver también 361, 370-371, 382. Sobre la extensión de la conflictividad entre territorios, Jáuregui y Vega, 2007, p. 933-937.

47 Entrevista a José Vicente Ojinaga. Fecha de realización: 17/04/2009. José Vicente Ojinaga nació en Bilbao en 1050. Fue trabajador de la Westinghouse y formó parte durante los años setenta de ETA VI/LCR/LKI.

48 Entrevista a Enrique Ramos (seudónimo). Fecha de realización: 09/06/2012. Fue trabajador de Sener y Guinea Hermanos y formó parte del sindicato LAB durante los años ochenta y noventa. 
¿eh?. Mucha gente, mucha gente que apoyaba....» ${ }^{49}$. Comparando aquellos momentos de huelgas y asambleas con la movilización obrera actual, Miguel Ángel Asporosa considera que: «era diferente, pero era más bonito, porque... yo creo que las siglas se difuminaban en el conjunto. Y ahí estábamos todos, en defensa de todos y de todo. Era espectacular (...) más bonito, más emotivo, más romántico... era diferente...» ${ }^{50}$. Otro histórico ugetista, Luis Miguel Pariza, también reconoce guardar: «recuerdos extraordinarios de aquellos años, porque fue el movimiento obrero, el movimiento sindical, de los trabajadores de la Babcock, que logramos la solidaridad del resto de trabajadores de Vizcaya a través de una gran huelga general» ${ }^{51}$.

La expectativa que embargaba a los manifestantes en el transcurso de aquellas movilizaciones y hacía estremecer sus cuerpos todavía prevalece en el recuerdo de lo sucedido. Mari Carmen Moreno, antigua trabajadora de Firestone y activa sindicalista desde los años sesenta, recuerda cómo arengaba a comienzos de 1976 a los cientos de congregados en una campa situada a las afueras de Bilbao, entusiasmada ante la sensación de fortaleza imparable que desprendía la estampa impresionante de multitudes en movimiento que acudían desde distintos puntos al llamamiento de las organizaciones y asambleas de clase. En aquellos momentos álgidos de la lucha ellarecuerda que: «... había un bidón lleno de agua. ¡Raca!. Tiraron el agua, me ayudaron a subir... Habíamos tenido una asamblea, lloviendo..., jarreando..., explicando. Fuerte..., estábamos fuertísimas... la gente $^{52} \gg$. Los y las activistas sentían que se trataba de momentos en los que como manifiesta Paco Vega: «la vida había cambiado enormemente» porque «el entusiasmo, la generosidad, entrega [...] me parecía algo absolutamente alucinante... Era subirse a un bidón y ganarse automáticamente la credibilidad de la gente» ${ }^{53}$. Este tipo de testimonios apuntan, en la línea

49 Entrevista a Txutxi Korres, realizada por Mentxu Irusta Laforga, (extracto).

${ }^{50}$ Entrevista a Miguel Angel Asporosa. Fecha de realización: 14/04/2009. Miguel Angel Asporosa nació en Portugalete en 1954. Desde muy joven trabó contacto con el sindicato UGT, en el que ha permanecido hasta la actualidad, en una larga trayectoria en la que ha ocupado distintos puestos de responsabilidad.

51 Entrevista a Luis Miguel Pariza.

52 Entrevista a Mari Carmen Moreno.

53 Entrevista a Paco Vega. Fecha de realización: 02/04/2009. Paco Vega nació en Portugalete en 1952. Fue trabajador de Aurrerá y miembro de Comisiones Obreras, combinando su labor con la militancia en el PCE. En 1977 abandonó el partido para pasar al EMK. 
señalada por Carme Molinero, que la transición transcurrió en un contexto de efervescencia movilizadora en la que la mayoría de los activistas creyó en algún momento sentir a su favor los vientos de la historia ${ }^{54}$. Cabe añadir también, en el caso de algunas mujeres participantes, que las emociones liberadoras desatadas en la protesta estuvieron investidas de un importante componente de género ${ }^{55}$.

El pasado de la lucha obrera se prolonga hacia el presente y asedia los espacios que en incontables ocasiones se mostraron atestados de trabajadores/as en huelga. Sumida en su recuerdo, Oliva Esteban rememora el aspecto que adquiría la plaza principal de Sestao durante los momentos de huelga: «La Naval subíamos por [calle] Cueto, Altos Hornos subía por la Iberia, La General y la Babcock por [la cuesta de] Galindo. O sea, es que era impresionante!». De modo muy similar, Rosa García evoca la imagen de las masas obreras que tomaban el pueblo, en un momento que identifica con «la culminación de todas las luchas que habíamos llevado hasta entonces [...] había gente del Valle de Trápaga, de Ortuella, de Gallarta, de Santurce, de Portugalete, de Barakaldo, de Sestao... o sea, había gente de todos los sitios. Había gente de toda la margen izquierda y de mucho más allá...». ${ }^{56}$. En un enclave de la memoria especialmente nítido y evocador, la entrevistada ofrece una imagen que conecta lugar, tiempo y emoción en la plaza principal, en donde su memoria asigna una presencia a los manifestantes, provocando un efecto espectral que superpone la imagen actual del lugar con la que ofrecía hace cuatro décadas:

«Salíamos de la fábrica, andando por la carretera (...) subíamos a la plaza de Sestao, que empezamos a nombrarla como Plaza Roja. Y allí todos los líderes sindicales, políticos y no sé qué intervenían. Desde luego, ¡era increíble!, ¡ cómo es que lo estoy viendo!. Subíamos la gente de la General y de la Babcock. Habíamos quedado en la hora de salida, subiendo por toda la cuesta de Galindo. Aquello era un río humano. ¡Era terrible, terrible...!» ${ }^{57}$.

La memoria de aquellos episodios de protesta pasó a formar parte de un espacio que quedó aislado y devastado en un tiempo que se mostró in-

\footnotetext{
54 Molinero, 2010, p. 43.

55 Beorlegui, 2017, pp. 47-62.

56 Entrevista a Rosa García.

57 Entrevista a Rosa García.
} 
misericorde con respecto a las fábricas y los proyectos de emancipación que estas habían albergado. El caudal de movilización y expectativa que emanaba de la atmósfera de combatividad obrera durante los últimos años de la dictadura se vio interrumpido para finales de los años setenta, coincidiendo con los inicios de una crisis que se prolongó durante la década siguiente y se tradujo en el cierre de cientos de empresas. Babcock Wilcox, Nervacero, Altos Hornos, Echevarría... fueron de las primeras empresas en sufrir los efectos de la reconversión industrial. Luego se sumarían otras, como General Eléctrica, Altos Hornos o Euskalduna. La ilusión que había prendido con fuerza en el espacio fabril se vio pronto sustituida por una melancolía inconsolable que vino a anunciar la defunción de un sujeto político, el proletariado que había ocupado el lugar de vanguardia de la lucha por el ansiado futuro del socialismo y de la revolución social $^{58}$. La década de los años ochenta fue experimentada como una espiral descendente y jalonada de fechas, marcada por la sensación de derrota y desaparición de un mundo obrero que todavía refulge con fuerza en la memoria de los y las antiguas militantes obreras.

\section{Melancolía por un tiempo en ruinas}

El análisis de las fuentes orales sugiere que la experiencia de la militancia obrera se estructura en la memoria a partir de dos temporalidades distintas: una marcada por la presencia de un futuro utópico y otra en la que ese estadio se ve arrastrado hacia el pasado y convertido en ruina. La capacidad afectiva el recuerdo provoca, a su vez, la emergencia de una nueva subjetividad, de tipo melancólico, que se sitúa en consonancia con la aparición de un mundo marcado por el desencanto y la sensación de derrota y abandono. Todo ello inviste a la memoria del período de un carácter aparentemente contradictorio, en el que los y las protagonistas hacen coincidir los inicios del periodo desindustrializador con los últimos remanentes eufóricos de la lucha obrera. Ello permite comprender que José Iza afirme que: «todavía, a nivel revolucionario, había bastante ruido a inicios de los años ochenta». En una situación de retroceso progresivo y un avance del desmantelamiento industrial que suponía miles de despidos,

58 Sobre el significado político de la emoción melancólica en el caso vasco, ver Beorlegui, 2017. Sobre la «tradición melancólica» de la izquierda, ver Traverso, 2017. 
las líneas más duras de actuación tendieron a imponerse en el seno del movimiento obrero ${ }^{59}$. Iza asegura que durante los momentos más duros de la protesta de las contratas de Lemóniz «salías igual que los vándalos, lo primero que pillabas, ahí entrabas, a saco, a fuego» ${ }^{60}$. El carácter ambivalente que adquiere esa época en la memoria queda sintetizado por Paz Marañón en su relato al plantear que: «había expectativas, Era un poco el no admitir, en plan derrotados, [...] el mantener la fuerza...» ${ }^{61}$.

Aunque los primeros años ochenta fueron prolijos en protestas, éstas no consiguieron recabar los apoyos masivos que se habían dado a mediados de la década anterior, poniendo de manifiesto la debilidad del movimiento obrero. La destrucción de puestos de trabajo creció a un ritmo imparable durante los años ochenta, alcanzando para mediados de la década uno de los niveles de paro más altos de toda Europa, el 23'6\%, llegando superar el $30 \%$ en localidades como Sestao ${ }^{62}$. El desempleo se cebó especialmente con la margen izquierda de la Ría del Nervión, perdiéndose aproximadamente el 50\% de empleo industrial entre los años 1975 y 1996, contándose las localidades de Barakaldo, Santurtzi, Portugalete y Basauri entre las más afectadas ${ }^{63}$. Como ha señalado Mikel Aizpuru, los factores sociales y culturales desempeñaron un papel de gran importancia en el «síndrome de fatalismo» que se apoderó de las poblaciones de la margen izquierda ${ }^{64}$. El desánimo y la incertidumbre se fueron apoderando de los colectivos mientras avanzaban los años ochenta, mientras las plazas que se habían abarrotado a mediados de la década anterior pasaron a quedar vacías ${ }^{65}$. A la hora de describir su vida en aquellos momentos, Joaquín Alcalde apela a la desesperación como emoción dominante tras conocer los despidos masivos anunciados en Nervacero: «nada... ni apoyo

59 Ruzafa, 2017, p. 12.

60 Entrevista a José Vicente Iza. Fecha de realización de la entrevista 20-12-2008. José Vicente Iza nació en Bilbao en 1949. A finales de los años sesenta emigró a Alemania a trabajar y a su trabajo fue contratado por Tabora, una contrata de Lemóniz, pasando posteriormente a los Altos Hornos. Formó parte de distintos movimientos obreros de corte asambleario.

${ }^{61}$ Entrevista a Mari Paz Marañón. Fecha de realización de la entrevista: 10-02-2009. Mari Paz Marañón nació en Medina de Pomar (Burgos) en 1952. Fue trabajadora de General Eléctrica y militante de Comisiones Obreras y MC/EMK.

62 Serrano, Susana, 2012, pp. 151-152.

63 Datos extraídos de Larrinaga, 2011, p. 58.

64 Aizpuru,, 2011, p. 167.

65 Ruzafa, 2017, p. 7. 
de nadie, ni futuro por ningún lado» ${ }^{66}$. En un panorama progresivamente ensombrecido por la incertidumbre y la falta de futuro, Mari Carmen Saiz confiesa que: «Llegó un momento en que yo lo viví mal porque daba la sensación de que nos quedábamos solas ${ }^{67}$.

Julia González también considera que los peores momentos de su dilatada trayectoria como militante comunista fueron a lo largo de los años setenta: «Esto era masivo, sabías que mucha gente tenía que salir ¡Ay, con los expedientes de regulación, con las listas...! Aquello fue muy doloroso muy duro, muy triste (...) Y entonces... pues claro, ya no había fuerza para luchar contra ello, no tenías ni moral, porque sabías que tenías la de perder, que no podías hacer nada». Esa pulsión pesimista que invoca la memoria del desmantelamiento fabril se prolonga en su caso hacia el presente, dejando tras de sí un sabor amargo ante la defunción de los ideales albergados en la fábrica: «aquellos han sido los mejores años - asegura Julia - de lucha, la vitalidad que has tenido, pero... es que es triste que no hayas conseguido (...) entonces teníamos una utopía que no se ha llegado a cumplir». Desesperanzada, la entrevistada advierte que su tristeza se ha ido acrecentado con el paso del tiempo, al considerar que una vez consumados los primeros cierres durante los años ochenta, «después ha sido mucho peor. Ya nadie ha protestado por nada (...) nos hemos convertido en nuevos ricos, gente que hasta hemos sido luchadora...» ${ }^{68}$.

En el caso de Ana Picaza, la experiencia de la desindustrialización estructura su memoria en dos temporalidades distintas. La primera, asociada a la atmósfera de reivindicación que dominaba en la fábrica a mediados de los años setenta, evoca la sensación de fortaleza y unidad experimentadas al participar del movimiento obrero, mientras que la segunda, referida al final de la década, da cuenta de la desaparición de esa afectividad en el entorno laboral y la aparición de una sensación de desasosiego y vacío. La pérdida del territorio asociado a la militancia configura en su caso una experiencia derrota que se ve dilatada en el tiempo como consecuencia de un prolongado proceso de rememoración que tiene como locus principal la fábrica y su entorno. La euforia, la ilusión y la melancolía que provoca

66 Entrevista a Amando Obregón.

67 Entrevista a Mari Carmen Saiz.

68 Entrevista a Julia González. Fecha de realización: 16-04-2009. Julia González nació en 1935 en La Rigada, Muskiz. Fue trabajadora de General Eléctrica y desde edad muy temprana formó parte del Partido Comunista de España, desarrollando una labor muy activa durante los años sesenta y setenta. 
la lectura retrospectiva de la entrevistada estructuran lo vivido en bloques semánticos diferenciados que arrojan una temporalidad muy esclarecedora de los efectos de la desindustrialización, del modo en que el pasado afectó $\mathrm{y}$ fue incorporado mediante el recuerdo:

«He pensado muchas veces en eso. La verdad es que los años primeros reivindicativos... los setenta, había una solidaridad tremenda. Se debatía mucho a todos los niveles. Había ilusión y muchos debates [...]. Desde el ochenta ya fue una cosa totalmente diferente. Se enrareció un poquito el ambiente entre la clase trabajadora, ya no tenía nada que ver con lo anterior, ya luego parecía que no era clase trabajadora aquello.» ${ }^{69}$

La devastación experimentada por el tejido industrial vizcaíno llenaría el paisaje de la ría de ruinas desvencijadas y fantasmagóricas, capaces de inquietar sobremanera a unas poblaciones edificadas en torno a la existencia de la fábrica. Ese carácter siniestro de las ruinas industriales está indisolublemente vinculado al lugar central que las fábricas habían ocupado durante la modernidad, seguido de un deterioro vinculado a su abandono. Lo que las convierte en entidades modernas y antiguas al mismo tiempo, en un estado híbrido que desafía las asunciones que han existido en torno a la modernidad, al progreso, al curso de la historia ${ }^{70}$. En el verano 1983, coincidiendo con la fase más álgida del desmantelamiento industrial, tuvieron lugar unas lluvias torrenciales que costaron decenas de vidas y provocaron un numero muy cuantioso de pérdidas en el tejido industrial ubicado junto a la ría del Nervión. Como plantea Ruzafa, ese fue un «momento psicológico» en el que la vulnerabilidad de las poblaciones más afectadas por la reconversión se hizo más evidente ${ }^{71}$. José Ramón Castaños recuerda la sensación apocalíptica que experimentó ante el cuadro que se dibujaba ante sus ojos, con unas zonas reducidas a escombros y cubiertas de fango: «Parecía que había habido una explosión nuclear, que había desaparecido la Margen Izquierda y Bilbao entero» ${ }^{72}$.

Junto a las inundaciones de 1983, el cierre del astillero Euskalduna es uno de los episodios más recurrentes en los relatos de vida estudiados, condensando un gran significado con respecto al quebranto sufrido por

\footnotetext{
69 Entrevista a Ana Picaza.

70 Olsen y Peturdottir, 2014, p. 6.

71 Ruzafa, 2017,p. 7.

72 Entrevista a José Ramón Castaños.
} 
el movimiento obrero durante los años ochenta. Desde finales de ese año Euskalduna se enfrentaba a plan de reconversión que suponía, en la práctica, su desmantelamiento, pese a la resistencia enconada por parte de la plantilla que se alargó durante varios meses y se fue radicalizando hasta convertirse en un verdadero problema de orden público. Como recuerda José Luis Longarte, el discurso emanado desde las instituciones en torno a la fábrica era que se trataba de una «chatarrería» que «no merecía la pena ${ }^{73}$. Las instalaciones estaban emplazadas a escasos metros del centro de la ciudad de Bilbao y tenían un indudable peso simbólico y sentimental en buena parte de la población local, tendente a identificarlo con la ciudad y con lo vasco. Todo esto es lo que permite comprender que alguno de los entrevistados identifique automáticamente el proceso con «una tragedia, un drama» ${ }^{74}$. Como recuerda Jon Fano, aquella imagen de «un cierto movimiento resistente» que se proyectó desde la fábrica a mediados de los años ochenta tenía lugar «ya en una situación de retroceso del movimiento obrero» ${ }^{75}$. La confrontación adquirió un carácter decisivo en relación al sostenimiento de la identidad obrera, pasando a representar en la memoria una especie de canto del cisne de la lucha fabril. Tal es la valoración que realiza José Ramón Castaños, que considera que Euskalduna representó «la última lucha de resistencia que merece llevar ese nombre». Su juicio es concluyente y sintetiza lo acontecido con posterioridad al cierre del astillero como: «Una especie de depresión colectiva del pueblo vasco» ${ }^{76}$.

Tal y como podía leerse en la prensa a inicios de los años noventa, las ruinas industriales «inundaban» Bizkaia, avanzando implacables a lo largo de toda la ría en un espacio calculado en 1993 como de 3.221 .000 metros cuadrados. Alarmadas ante la extensión del fenómeno, las autoridades competentes optaron por una política de demoliciones, destacando entre las razones aducidas para ello la «imagen de antigüedad» proyectada por las fábricas abandonadas, el «impacto visual negativo» que trasmite «...la imagen de un período de nuestra historia industrial ya agotado». La nueva configuración prevista en el espacio definido como «escenario futuro», pasaba por la construcción de una sociedad de consumo ideal, sin memo-

\footnotetext{
73 Entrevista José Luis Longarte.

74 Entrevista a Luis Alejos.

75 Entrevista a Jon Fano.

76 Entrevista a José Ramón Castaños.
} 
ria ni antagonismos sociales ${ }^{77}$. Euskalduna fue una de las primeras fábricas en ser derruidas. Miguel Angel Asporosa, que como ugetista apoyó el cierre de la fábrica, considera que «era doloroso hacerla desaparecer, es verdad, era también una empresa competitiva... pero desgraciadamente para ellos, para nosotros, para todos... estaba en el centro de la Ría. Y tal y como se estaba desarrollando Bilbao...» ${ }^{78}$. Luis Miguel Pariza, que defendió una postura similar con respecto a Babcock Wilcox, entiende que «con la perspectiva del tiempo, se podían haber hecho mejor las cosas» dado que fue «una de las empresas más importantes del País Vasco y de España» ${ }^{79}$. Como ha planteado con gran brillantez el antropólogo Gastón Gordillo, los escombros son parte de la configuración social y afectiva de un lugar, en tanto que revelan las fuerzas violentas constitutivas del paisaje en una sedimentación material de la destrucción que une el pasado con el presente y el futuro ${ }^{80}$. Las implicaciones de esta concepción negativa del espacio son muy importantes, en tanto permiten analizarlo a partir de los lugares que fueron negados para crear las geografías del presente. Ello permite comprender la sensación de ausencia que desprenden las palabras de Loli, una de las entrevistadas en el documental de Larraitz Zuazo sobre las mujeres de Euskalduna, cuando evoca con voz temblorosa que: «Me dio muchísima pena la primera vez que bajamos a ver lo que es... lo que había sido Euskalduna, que no estaba....» ${ }^{81}$.

El análisis con regiones aledañas e incluso países distintos permite arrojar algo más de comprensión sobre las devastadoras consecuencias de los procesos desindustrializadores acaedidos durante las dos últimas décadas del pasado siglo veinte. En la vecina Gipúzkoa, tal y como recoge en su libro sobre Luzuriaga Koldo Izagirre, el cierre de la fábrica de Luzu-

77 Las actuaciones acometidas para la altura de diciembre de 2013 contabilizaban un total de 49 intervenciones en el espacio del Bilbao metropolitano, acabando con más de 154 hectáreas de terreno industrial, más de la mitad del cómputo general de superficie modificada en el territorio vasco. Datos disponibles en la web del Departamento de Medio Ambiente, Planificación Territorial y Vivienda. Disponible en http://www.ingurumena. ejgv.euskadi.eus/r49-565/es/contenidos/informacion/ruinas_industriales/es_1159/ruinas_c. html, Consultado el 14-07-2017. Ver también Alvarez, Alfonso, «Bilbao. La definición de una imagen de marca como reclamo competitivo. Crónica de un proceso iniciado», Ciudades, 5, 1999, 174

${ }^{78}$ Entrevista a Miguel Ángel Asporosa.

79 Entrevista a Luis Miguel Pariza.

80 Gordillo, 2014,pp. 10-11.

81 Zuazo, 2016. 
riaga en la localidad de Pasajes también provocó una fuerte oleada de melancolía con respecto a un mundo arrojado a la escombrera de la historia: «Era nuestro trabajo, pero ya no importa nada», refiere una de las entrevistadas $^{82}$. En unos pocos años, en palabras de otro de los entrevistados, la fábrica ubicada en el cinturón industrial donostiarra se había convertido «en una cosa vieja» ${ }^{83}$. Los trabajos de Rubén Vega y su equipo dan cuenta del clima de conflictividad y los efectos traumáticos que tuvo la desindustrialización para el caso asturiano ${ }^{84}$. Contamos también con estudios dedicados al puerto de Sagunto ${ }^{85}$. La mayoría de los estudios realizados en torno a la cuestión han tendido a enfatizar los efectos disruptivos provocados por los cierres de las fábricas, la fractura generacional y lo que algunos autores han denominado la «doble borradura» de las vidas y memorias de las clases trabajadoras ${ }^{86}$. Para el caso escocés, que cuenta con procesos de reordenación urbana que, como el de Glasgow, guardan notables similitudes con el de Bilbao, Andrew Pechard ha planteado la existencia de profundas «heridas culturales» en toda una generación de «hombres rotos» por las políticas neoliberales de Margaret Thatcher ${ }^{87}$. Los trabajos coordinados por Steven High también han aludido al poder explicativo del paisaje postindustrial en Canadá y Estados Unidos, que ha pasado de representar la modernidad y el progreso a convertirse en metáfora de soledad, derrota y abandono ${ }^{88}$.

Un nuevo elemento vino a sumarse desde finales de los años setenta al cuadro siniestro que ofrecían las naves abandonadas a lo largo de la ría. Aunque exceden las posibilidades de este estudio, los heroinómanos se convirtieron figuras arquetípicas de la margen izquierda, donde el consumo de la sustancia alcanzaría dimensiones verdaderamente epidémicas. Lejos de proyectar la aureola reivindicativa del mañana revolucionario, «ser obrero» aparecía ante estas subjetividades como «algo asqueroso», optando, en palabras de un coetáneo, por «la huida como el motor que mueve toda ambición» ${ }^{89}$. La descripción que Mario García arroja de su

82 Entrevista a Madalen Ibañez, en Izagirre, 2013, p. 231.

83 Entrevista a Enrique Cerdán, en Izagirre, 2013. p. 103.

${ }^{84}$ Holm-Detlev, 1997.

85 Saez García, 2009. Bodí , 2015.

${ }^{86}$ High, Mackinnon, Perchard, 2017, p. 6.

87 Perchard, 2013, pp. 78-80.

88 HIGH, 2007.

89 Goikoetxea, Tomás, «Desde la Margen Izquierda. Ser obrero es sencillamente asqueroso», Punto y Hora, 18-25 de octubre de 1979, p. 26. 
barrio, que había definido anteriormente como una comunidad obrera, de idea de los cambios introducidos a raíz de la entrada del poderoso opiáceo: «Vuelvo y me encuentro que la heroína está empezando a hacer estragos, estragos de verdad - recuerda García - En cuatro años ha dado tiempo a que muchos jóvenes del barrio, muchísimos, y de los alrededores, estén enganchaos» ${ }^{90}$. Los cuerpos esqueléticos y prematuramente arruinados de los adictos se convertirían entonces en elementos asimilados al paisaje urbano, como reflejaría Eloy de la Iglesia en 1983 con su película «El pico» ${ }^{91}$. El paralelismo entre la desindustrialización, las drogas y la inexistencia de futuro también quedarían reflejadas posteriormente por Imanol Uribe en «Adiós Pequeña» (1986), y por Enrique Urbizu en «Todo por la pasta» (1990), productos cinematográficos que se ambientan en un escenario de degradación material en el que los protagonistas se funden con el ocaso del mundo fabril ${ }^{92}$. Mari Carmen Moreno, que se convirtió en trabajadora social tras el cierre de su fábrica, se estremece al recordar aquel tiempo marcado por los estragos de la heroína: «fue una época... del ochenta y cinco p'adelante - evoca con dolor la entrevistada - la gente se moría...». Su recuerdo se detiene en la imagen de una joven reclusa que fue a visitar a la cárcel de Basauri, la misma en la que había estado encerrada a mediados de los años setenta: «una chica que estaba, toxicómana, en el mismo sitio donde había estado [yo presa]. Fue una experiencia...» ${ }^{93}$.

El panorama que ofrecía Bilbao a mediados de los años noventa era dantesco, siendo aprovechado por el director Daniel Calparsoro para rodar en 1994 su película Salto al Vacío, que mostraba, en palabras de un crítico cinematográfico «los paisajes más feos y monstruosos de Sestao, las ruinas industriales de los Altos Hornos de Vizcaya y las decrépitas viviendas obreras, paisajes que llegan a recordar a películas como Blade Runner por sus tonos grises, la falta de luz y la humedad permanentes» ${ }^{94}$. Al año siguiente se desmanteló definitivamente el conocido como Horno de María Ángeles, uno de los más emblemáticos de

90 Entrevista a Mari Carmen Moreno.

91 De la Iglesia, Eloy (dir.), «El pico», 1983.

92 Uribe, Imanol, (dir.), «Adios Pequeña», 1986. Urbizu, Enrique (dir.), «Todo por la pasta», 1990.

93 Entrevista a Mario García.

94 «El joven cineasta vasco Daniel Calparsoro conmociona Berlín», $A B C$, 19-02-95, p. 103 . 
la capital vizcaína ${ }^{95}$. Este tipo de afirmaciones corroboran el abandono del que fue objeto de la zona, motivando que en el año 1997, el diario Le Monde se refería a Bilbao como una ville sinistrée, una ciudad devastada y monstruosa ${ }^{96}$. En esos años, las ruinas despertaron un creciente interés artístico y antropológico y fueron interpretadas como un símbolo de la decadencia, el abandono, y las fuerzas destructivas que entraña la modernidad, pasando a asemejarse a inmensas esculturas que extraían su significado del hecho de constituir el vestigio material y estético «de un modo de vida y un modo de organización social, política y económica, que dio sus frutos y se extingue dejando únicamente una capa sedimentaria de memorias» ${ }^{97}$.

La obsesión memorial en torno a algunos aspectos relativos al pasado industrial ha constituido a lo largo de los últimos años un verdadero fenómeno que algunos autores han denominado peyorativamente smokestack nostalgia (nostalgia de chimenea) ${ }^{98}$. Los afectos que se establecen con el pasado a partir de la fuerza estética de las ruinas industriales no comportan necesariamente un desinterés en las personas que los habitaron y las actividades que tuvieron lugar en ellos, dado que permiten recorrer los espacios de la memoria y derivar en conexiones contingentes y no causales, tomando contacto con un tiempo espectral que asedia al presente y porta consigo los proyectos que no fueron realizados en el pasado ${ }^{99}$. Asumiendo que la emoción que desprende el recuerdo de los entrevistados es eminentemente nostálgica, cabría añadir otros epítetos como «restorativa», «proactiva», o incluso «radical», al hacer desprender de ésta un profundo sentido de agencia histórica ${ }^{100}$. El relato de Enrique del Hoyo da cuenta de ese poder evocador de la fábrica y de los afectos que instaura, cuando rememora la atmósfera de combatividad que recorría toda la margen de la ría, recorriendo mentalmente toda una serie de lugares que permanecen vivos en su memoria viéndose empujado a un gesto nostálgico

95 Larrauri, Eva, «La última colada», El País, 03-07-1996.

${ }^{96}$ Citado en Vivas y Arnaiz, 2006, p. p. 125.

97 Vivas y Arnaiz, 2006, p. 132. Cabe citar los trabajos fotográficos «Viaje al paraíso perdido del socialismo vasco», de Carlos García Pozo, publicada parcialmente en El Mundo el 13-09-2016, o las series «Fénix», de José Luis Ramírez, o «Deriva de la Ría, paisajes sin retorno» (1994), de Carlos Cánovas, ambas de 1994. Desde un enfoque antropológico, Zulaika, 2006, pp. 173-192 y Zulaika, 2001,1-17.

98 Strangleman, 2013. Hill, 2013.

99 Edensor, 2005, p. 101.

100 Boym, 2005, p. 35, 255-260. 
con respecto a la lucha que allí existía: «Empieza Aurrera, Tarabusi, Euskalduna - enumera Del Hoyo - Y luego ya... andando por toda la orilla [desde Santurce a Bilbao] [...] mirando un poquito lo que pasó, cuando aquello... pues echas de menos un poquito aquella organización obrera que había»101. Como ha planteado Jackie Clarke para el caso de Francia, la evocación de la solidaridad, la lucha y otros componentes identificados con el extinto mundo obrero posibilitan una narrativa del pasado compartido, una alternativa al eterno presente del neoliberalismo, que se construye a partir de futuros pasados que se mantienen vivos por pequeñas comunidades de memoria ${ }^{102}$.

La conformación de la Asociación Museo Minero de Gallarta en 1986 es una clara muestra del poder evocador de las emociones. La reducción a chatarras y escombros de las fábricas que habían sido símbolo de progreso y modernidad invita a repensar el significado de la modernidad, a la luz de la velocidad adquirida por el paso del tiempo y la reacción melancólica que provoca en la memoria. Tal y como puede leerse en su página web, la asociación se creó en los momentos álgidos del proceso de desindustrializacion «entre otros por ex mineros y trabajadores de la siderurgia, que ven, en plena crisis industrial, como los elementos que han formado parte de lo que hasta ese momento había sido la esencia de Bizkaia, empiezan a ser abandonados». Una sensación de amenaza similar es la que se cernía sobre la mina en la que se emplaza el museo, como relata José Vicente Iza, que se crió en ese lugar: «Me da pena porque hubo unos comentarios que sí querían rellenar (la mina) o no sé qué rollos. Era.... pues no sé, enterrar un poco el orgullo de Gallarta y de la zona minera de aquellos años...». Resulta igualmente significativo en ese sentido que la entrada al museo esté precedida por el último «tocho» de hierro que salió de los Altos Hornos, como si condensara de algún modo una parte del significado de una época que sólo se mantiene viva por medio del recuerdo. En palabras de Carmelo Uriarte, principal impulsor del proyecto, su búsqueda incesante de materiales abandonados entre las ruinas industriales y las minas comenzó: «por pura añoranza, por sentimentalismo - explicaba en 2007 - Primero tornillos y tenazas, pero luego fui rescatando barrenas, taladros, vagonetas... cada vez más cosas» ${ }^{103}$. El documental «Crónicas desde la Arboleda», también arroja algunas claves interpretativas sobre la

\footnotetext{
101 Entrevista a Enrique del Hoyo. Realizada por Mentxu Irusta Laforga (extracto).

102 Clarke, 2015, pp. 107-125.

103 Izagirre, 2008, p. 17.
} 
irresistible pulsión melancólica que llevó a Carmelo y otros como él a lanzarse a recuperar aquellos objetos, sumergidos en un mar de chatarra irreconocible, investidos con el aura de un pasado agónico y silenciado: «Había visto una mina, movimiento, vitalidad... ya no era más que un montón de escombros. Es verdad... me daba pena, se me caía el alma a los pies... ¿Por qué? Porque eran mis raíces, lo que yo había vivido siempre...» ${ }^{104}$.

La historia del museo y de sus voluntarios constituyen un magnífico ejemplo del «deber de memoria» que introduce el gesto nostálgico del recuerdo con respecto al pasado industrial. El desinterés, cuando no hostilidad, que han mantenido las autoridades con respecto a su labor incesante, adquiere un significado muy concreto en relación a lo que algunos autores han denominado «las políticas de la memoria». El significado de los espacios, en ese sentido, depende de los modos en que se emplazan en un contexto social e histórico, lo que vendría a permitir, en palabras de Robert Bevan, una «saturación ideológica» si se atiende a las razones por las que determinados edificios son levantados, preservados o destruidos ${ }^{105}$. Más centradas en las posibilidades turísticas y urbanísticas de las naves y solares vacíos, las administraciones del Partido Socialista y el Partido Nacionalista Vasco han vuelto la espalda hacia un pasado percibido como distante, incómodo e incluso ajeno. Donde los expertos veían chatarra y escombros carentes de valor, obstáculos para el futuro, Carmelo y el resto de miembros de la asociación Museo Minero veían unos lugares y unos objetos cargados de significado. Tal y como permite apreciar una carta dirigida a las autoridades en 2015 , la recuperación de materiales por parte de estos trabajadores jubilados y su entorno más cercano fue denostada durante décadas por parte de los especialistas en patrimonio: «muchas veces nos hemos sentido solos defendiendo valores que pertenecen a todos - denunciaban desde la asociación - Nos hemos sentido solos también recuperando la «chatarra» y defendiendo esa chatarra frente a los auténticos chatarreros. SÍ, lo que se denominaba chatarra y nosotros decíamos que era importante conservar» ${ }^{106}$. El diagnóstico realizado desde la asociación, en la que participaban varios antiguos sindicalistas, no sólo incluye una aguda percepción de las fuerzas que han reducido a chatarra el patrimonio industrial, sino que incluye una dignificación y valoración de

104 «Crónicas desde la Arboleda». Documental

105 Bevan, 2016,p. 12.

106 «Comunicado del Museo Minero sobre el posible cierre del centro de Peñas Negras en Meatzaldea».03-10-2015. 
esos materiales, que se identifican discursiva y emocionalmente con el mundo obrero. La soledad de estos voluntarios y la dejación institucional contrastan poderosamente con las reivindicaciones y las actuaciones que se han llevado a cabo, por ejemplo, en el caso de Sagunto, donde a pesar de existir fuertes polémicas se han dado iniciativas favorables a la conservación y musealización de los Altos Hornos y otros espacios ${ }^{107}$.

La interacción de los antiguos trabajadores de la siderugia y la mineria con los objetos recuperados a la destrucción y olvido resulta muy indicativa del modo en que el pasado se prolonga hacia el presente y modelado por el. Lejos de la veneración y la aproximación más convencional a la pieza exigida por los expertos en conservación, la función última de la operación de recuperación, como explicaba el propio Carmelo en 2007, es ensamblar los materiales recogidos para poder devolver al objeto su función original: «Te parecerá chatarra... pero con eso vamos a reconstruir otra vagoneta. Porque aquí no creamos nada nuevo [...] Rescatamos piezas que están perdidas o enterradas en las galerías y las volvemos ensamblar con las técnicas y las herramientas de antes» ${ }^{108}$. En una visita al museo en julio de 2017, otro de los voluntarios me comentó que su mayor motivación a la hora de participar en la asociación no era el hecho de encontrar las piezas, sino de «devolverles la vida» al hacer que funcionaran de nuevo, valiéndose si era preciso de varias máquinas para reparar una. Las menciones que Uriarte realiza en el documental al «alma» de los objetos del museo también apuntan en el mismo sentido de unir inextricablemente materialidad, subjetividad, emociones y recuerdos. La reivindicación de esos objetos está movida por el poder afectivo de la memoria, como parte de un gesto de resistencia frente a la primacía del presente y de la novedad, que aparecen como los valores absolutos de nuestro estadio y definen las coordenadas de tiempo y espacio en la ciudad.

\section{Conclusiones}

La entrada en el nuevo milenio vino acompañada de nuevas promesas de modernidad vinculados a la apuesta institucional por el pujante sector del turismo. La capital vizcaína no fue una excepción al renovado optimismo de los años noventa, un momento marcado por la bonanza económica y la

107 Bodí, 2015, pp. 108-122.
108 Izagirre, 2008, p. 20.

Historia Contemporánea 58, 2018: 815-847 
conversión de la ciudad en un centro de consumo inserto en el circuito turístico europeo y global. «Bilbao ha cambiado su destino», podía leerse en la prensa local, «los nuevos proyectos de la ciudad continúan un camino de progreso cuya ruta marcó el museo Guggenheim» ${ }^{109}$. El espacio de ruina, de vacío y de ausencia que todavía persiste a lo largo de la ría como consecuencia del proceso desindustrializador es, sin embargo, mucho mayor que el que ocupa el museo, cuyo sólido titanio contrasta con las grietas de una memoria que sangra en el tiempo como consecuencia de la defunción de los ideales de clase. La memoria del mundo obrero, sus lugares comunes, los referentes simbólicos y materiales... se vieron vertiginosamente arrasados por el espacio liso de la nueva ciudad posmoderna, consagrada para el consumo, sumida en un presente estático sin pasado ni futuro. El cierre y demolición de los factorías, en ese sentido, no sólo entrañó una brutal transformación de la ciudad, sino que alteró sustancialmente las coordenadas espacio-temporales de una varias generaciones forjadas entre el humo y el fragor de las fábricas, testigos del fulgor y la ruina de la identidad obrera.

La fábrica y su recuerdo adquieren una materialidad que revela tanto el paso del tiempo devastador de la modernidad como la resistencia a su desaparición, ejerciendo un poderoso influjo en aquellos que, en otro tiempo, llenaron de vida el interior de aquellos espacios. Su poder afectivo permite trasladar esa ambivalencia semántica al recuerdo de las fábricas que albergaron la gestación y la sepultura de grandes proyectos de transformación que pasaron a quedar reducidos a un puñado de escombros. La melancolía provocada por la ruina industrial en aquellas subjetividades edificadas desde los postulados obreristas invita a repensar los parámetros de éxito en los que se cimentan las sociedades modernas, los mismos que se ven sacudidos por emociones y memorias que prolongan el pretérito hacia el presente, alargando su vida mediante el recuerdo. El progreso, en ese sentido, no ha de confundirse con el olvido de quienes protagonizaron los últimos momentos del largo siglo industrial vizcaíno, recorriendo la ría en su trasiego diario e impulsando algunas de las movilizaciones más importantes y multitudinarias que allí se han conocido. Resulta evidente, en ese sentido, que el patrimonio industrial de la región ha sido infravalorado, como también lo ha sido el pasado de luchas y reivindicaciones, o el proceso de recuperación de la memoria que, pese a todo, vienen desarrollando desde hace décadas asociaciones como la del Museo Minero de Gallarta.

109 Saez, Olga, «Bilbao siglo XXI», Bilbao, 155, diciembre 2006, pp. 8-9. 


\section{Bibliografía}

Alvarez, Alfonso, «Bilbao. La definición de una imagen de marca como reclamo competitivo. Crónica de un proceso iniciado, Ciudades, 5, 1999, pp. 151-158.

AizPuru, Mikel, Barakaldo, una ciudad industrial. Esplendor crisis y renovación. 1937-2004, Ediciones Beta, Bilbao, 2011

Bajtin, Mijail, Teoría y estética de la novela, Madrid, Taurus, 1989.

Baumann, Zygmunt, Modernidad Líquida, Madrid, Fondo de Cultura Económica, 2002.

BeORlegui, David, Transición y melancolía. La experiencia del desencanto en el País Vasco (1976-1986), Postmetrópolis, Madrid, 2017.

Beorlegui, David «Expectativas de género en las luchas obreras del tardofranquismo y la transición. Feminismo y memoria en el Gran Bilbao 19761979», Historia Social, 88, 2017, pp. 47-62.

BERMAn, Marshall Todo lo sólido se desvanece en el aire. La experiencia de la modernidad, México, Siglo XXI, 1989.

Benjamin, Walter, Tesis sobre la Historia y otros fragmentos, México, Universidad Autónoma de la Ciudad de México-Itaca, 2008.

Bevan, Robert, The Destruction of Memory. Architecture at War, Reaktion Books, London, 2006.

Bodí, Jordi, De Chatarra a Patrimonio. El proceso de patrimonialización de las antiguas instalaciones sidero-metalúrgicas de Puerto de Sagunto (19842014), Tesis dirigida por Beatriz Santamarina Campos. Departament de Sociologia i Antropologia Social, 2015.

Boym, Svetlana, The future of nostalgia, New York, Basic Books, 2001.

Clarke, Jackie, «Closing Time. Deindustrialization and Nostalgia in Contemporary France», History Workshop Journal, 79, 2015, pp. 107-125.

Conerton, Paul, How Modernity Forgets, Cambrigde, Cambridge University Press, 2009

CowIE, Jefferson, HeAthCotT, Joseph, (eds.), Beyond the Ruins. The Meanings of Deindustrialization, Ithaca-NY, Cornell University Press, 2003.

Cristobal, Antonio, AzPIROz, José Miguel, «Crónicas de la Arboleda». Documental. 2013.

De la IGLesia, Eloy (dir.), «El pico», 1983.

Deleuze, Gilles, GuatTari, Félix, Mil Mesetas. Capitalismo y Esquizofrenia, Valencia, Pre-textos, 2004.

DoMÉNECH, Xavier, Cambio político y movimiento obrero bajo el franquismo. Lucha de clases, dictadura y democracia, Barcelona, Icaria, 2012.

EDENsor, Tim, Industrial Ruins. Space, Aesthetics, Materiality, Oxford, Berg, 2005

FRISCH, Michael, A Shared Authority: Essays on the Craft and Meaning of Oral and Public History, New York, SUNY Press, 1990. 
GÁLVEZ, Sergio, «El movimiento obrero en la España del tiempo vivido: del «sujeto político» al «nuevo precariado», Cuadernos de Historia Contemporánea, vol. 30, 2008,199-226.

GlAZER, Peter, Radical Nostalgia. Spanish Civil War Commemoration in America, Rochester, NY, University of Rochester Press, 2005.

GonZÁlez-PoRTILla, Manuel. Los orígenes de una metrópoli industrial: la ría de Bilbao, Bilbao, Fundación BBVA, 2001.

Gordillo, Gastón, Rubble, The afterlife of destruction Duke University Press, 2014.

HILL, Lisa, «Archaeologies and geographies of the post-industrial past: landscape, memory and the spectral», Cultural Geographies, 20 (3), 2013, pp. 379-396.

High, Steven, Mackinnon, Lachlan, Perchard, Andrew, The Deindustrialized World: Confronting Ruination in Postindustrial Places, University of British Columbia, Vancouver, 2017.

High, Steven, Lewis, David. K., Corporate Wasteland. The Landscape and Memory of Deindustrialization, Cornell University Press, Ithaca-New York, 2007.

Holm-Detlev, Köhler (coord..), Asturias, el declive de una región industrial, Trea, Gijón, 1997.

Huyssen, Andreas, «Authentic Ruins: Products of Modernity», en Hell, Julia, Schönle, Andreas (eds.), Ruins of Modernity, Durham, NC, Duke University Press, 2010.

Ibarra, Pedro, Memoria del Antifranquismo en el País Vasco. Por qué lo hicimos (1966-1976), Pamplona, Pamiela, 2016.

IZAGUiRRE, Ander, Cuidadores de mundos. El biógrafo de los pedruscos, el constructor de calaveras, el hombre de las doscientas fuentes y otras memorias vivas del País Vasco y de Navarra, Barcelona, Altair, 2008.

IzAGIRRE, Koldo, Luzuriaga. Voz y vida obrera, Ayuntamiento de Pasaia, Pasaia, 2013.

JÁuregui, Fernando, Vega, Pedro, Crónica del antifranquismo, 1939-1975. Todos los que lucharon por devolver la democracia a España, Barcelona, Planeta, 2007.

LARRINAGA, Carlos, «Regeneración urbanística y nuevas opciones de las ciudades post-industriales: el caso de Bilbao», Transporte, Servicios, Comunicaciones, 21, Diciembre 2011

LlONA, Miren, «Historia en obras: memorias, emociones y subjetividad», en Pérez-Fuentes, Pilar (ed.), Subjetividad, cultura material y género. Diálogos con la historiografía italiana, Barcelona, Icaria, 2010, pp. 153-169.

MAH, Alice, Industrial Ruination, Community and Place: Landscapes and Legacies of Urban Decline, Toronto, University of Toronto Press, 2012.

MEJÍA, Julio, «El muestreo en la investigación cualitativa», Investigaciones Sociales, 5, 2000. 
Molinero, Carmen «La transición y la «renuncia» a la recuperación de la «memoria democrática», Journal of Spanish Cultural Studies, 11 (1), 2010, pp. 33-52.

NAVARO-YASHIN, Yael, «Affective spaces, melancholic objects: ruination and the production of anthropological knowledge», Journal of the Royal Anthropological Institute, 15, 2008, pp. 1-18.

Olsen, Bjornar, Peturdottir, Pora, Ruin Memories. Materiality, Aesthetics and the Archaelogy of the Recent Past, Routledge, New-York, Oxon, 2014.

PERCHARD, Andrew, «Broken Men and Thatcher's Children: Memory and Legacy in Scotland's Coalfields», International Labor and Working Class History, 84 (2013), pp. 78-98.

PÉrez, José Antonio, Los Años del Acero, Madrid, Biblioteca Nueva, 2001.

PÉREZ, José Antonio: «Historia (y memoria) del antifranquismo en el País Vasco, Cuadernos de Historia Contemporánea, 35, 2013.

Perks, Robert, Thomson, Alistair, The Oral History Reader, London-New York, Routledge, 2003.

Rubio, Coro, De la Granja, José Luis, De Pablo, Santiago (ed): Breve historia de Euskadi. De los Fueros a la Autonomía, Debate, Barcelona, 2011.

RuIZ, David: Historia de las Comisiones obreras (1958-1988), Siglo XXI, Madrid, 1993.

Rolnik, Suely, GuAtTARi, Felix, Micropolítica. Cartografías del Deseo, Madrid, Traficantes de sueños, 2006.

RUZAFA, Rafael, «Caras tristes de un proceso histórico. La desindustrialización de la Ría de Bilbao en el último cuarto del siglo XX», Historia Trabajo y Sociedad, 8 (2017).

SAEz García, Miguel Ángel, DíAz Morlán, Pablo, El puerto del acero, Marcial Pons, Madrid, 2009.

SERRANO, Susana «Despegue, expansión, crisis y reconversión (1869-2000). La vida del eje industrial vertebrado por la ría de Bilbao», Lan Harremanak, 6, 2012, pp. 133-160.

Soto Álvaro, Aroca, Manuela (dir), Combates por la democracia. Los sindicatos de la dictadura a la democracia. 1938-1994, Madrid, Universidad Autónoma de Madrid- Fundación Largo Caballero, 2012.

SoJA, Edward, Postmodern Geographies. The Assertion of Space in Critical Social Theory, London-New York, Verso, 1989.

Strangleman, Tim, «Smockestack Nostalgia. Ruin Porn or Working Class Obituary: The Role and Meaning of Deindustrial Representation», International Labor and Working-Class History, 84, Fall 2013, pp. 23-37.

Traverso, Enzo, Left-Wing Melancholia, Marxism, History and Memory, Columbia University Press, New York, 2017.

VAtтімo, Gianni, El fin de la modernidad, Nihilismo y hermeneutica en la cultura posmoderna, Cedisa, Barcelona, 1986. 
VIVAs, Isusko, «El último horno alto de la Ría se tambalea», Bilbao, 220, noviembre 2007, p. 37.

VIVAS, Isusko, ARNAIZ, Ana, «Un cementerio industrial de ruinas escultóricas en la ciudad de Bilbao», Fabrikart: arte, industria, tecnología, sociedad, 6, 2006.

URIBE, Imanol (dir.), «Adios Pequeña», 1986.

URBIZU, Enrique (dir.), «Todo por la pasta», 1990.

ZuAzo, Larraitz, Nosotras, las mujeres de Euskalduna, 2016.

ZULAIKA, Joseba, «Las ruinas de la teoría y la teoría de las ruinas», Revista de Antropología Social, 15, 2006, pp. 173-192.

ZulaIKA, Joseba, «Tough Beauty: Bilbao as Ruin, Architecture and Allegory», en ResinA, Joan Ramón, (ed.), Iberian Cities. New York, Routledge, 2001, pp.1-17.

\section{Financiación}

Este trabajo ha contado con la financiación del grupo Experiencia moderna GIU 17/37 y del proyecto de investigación Historia Intelectual de la Política Moderna. HAR2017-84032-Ministerio de Economía y Competitividad del Gobierno de España, AEI, FEDER. Grupo IT615 Universidad del País Vasco.

\section{Datos del autor}

David Beorlegui (dbeorza@yahoo.es) es doctor en Historia Contemporánea por la Universidad del País Vasco (2016). Entre sus obras y artículos publicados, destacan Transición y Melancolía. La experiencia del desencanto en el País Vasco (1976-1986), Postmetrópolis, Madrid, 2016 y Denon Artean/Entre todas, Ayuntamiento de Getxo, 2018, así como los artículos «Expectativas de género en las luchas obreras del tardofranquismo y la transición, feminismo y memoria en el gran Bilbao», Historia Social, 88, 2016, o "Vitoria, brothers, we do not forget. The public history of the strikes of Vitoria and the Spanish Transition to democracy", con publicación prevista para otoño de 2018 en la revista Oral History. En la actualidad, forma parte del grupo de investigación Experiencia Moderna y del grupo Historia Intelectual de la Política Moderna, donde trabaja como investigador postdoctoral contratado. Es coeditor de la revista electrónica bilingüe Palabras y Silencios/ Words and Silences y representante de la región europea en la International Oral History Association (IOHA). 